\title{
Measures for infection control in a Carbapenem-resistant Enterobacteriae carrier post open heart surgery in the cardiac intensive care unit: A case report
}

\author{
Gurpreet Singh', Simon Jerome Vendar
${ }^{1}$ Department of Cardiothoracic Surgery, Hospital \\ 'Department of Cardiothoracic Surg
Sultanah Aminah, Johor Bahru, Malaysia \\ ${ }^{2}$ Department of Infectious Disease, Hospital Sultanah \\ Aminah, Johor Bahru, Malaysia
}

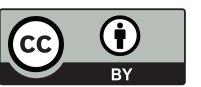

This work is licensed under a

Creative Commons Attribution 4.0

International License

\section{Received: 2020-03-27 \\ Accepted: 2020-04-08 \\ UDC: 616.1}

\section{J Clin Med Kaz 2020; 3(57):45-47}

Corresponding author: Gurpreet Singh, Department of Cardiothoracic Surgery, Hospital Sultanah Aminah, Johor Bahru, Malaysia.

E-mail: gurpz 91@yahoo.com

\section{n', Syed Rasul G Syed Hamid ${ }^{1}$, Masliza Zaid ${ }^{2}$}

\section{ABSTRACT}

The prevalence of Carbapenem-resistant Enterobacteriaceae infection in a hospital setting is on the rise. Once infected, it is associated with increased morbidity as well as mortality. The common isolates of a Carbapenem-resistant Enterobacteriaceae infection is Klebsiella pneumoniae. In this case report, we discussed on a patient who is a Carbapenem-resistant Enterobacteriaceae carrier that underwent an open heart surgery in a government hospital in Johor Bahru, Malaysia. On the whole, our objectives were to identify risk factors that warrants a patient to be screened for Carbapenem-resistant Enterobacteriaceae infection and once a Carbapenem-resistant Enterobacteriaceae infected patient is detected, what are the measures that can be implemented to prevent and control spread of infection particularly in the intensive care unit setting.

Key words: Carbapenem-resistant Enterobacteriaceae, open heart surgery, intensive care unit, infection control

ЖУРЕК РЕАНИМАЦИЯ БӨЛІМШЕСІНДЕ АШЫК ЖУРЕК ХИРУРГИЯСЫНАН КЕЙІН КАРБАПЕНЕМГЕ ТӨЗІМДІ ЭНТЕРОБАКТЕРИЯ ТАСЫМАЛДАУШЫСЫНА АРНАЛҒАН ИНФЕКЦИЯЛЫҚ БАҚЫЛАУ ШАРАЛАРЫ: КЛИНИКАЛЫК ЖАҒДАЙ

Г. Сингх ${ }^{1}$, С.Дж. Вендаргон", С.Р. Хамид', М. Зайд²

${ }^{1}$ Кардиоторакалды хирургия бөлімшесі, Сұлтан Амин ауруханасы, Джохор-Бару, Малайзия

${ }^{2}$ Инфекциялық аурулар бөлімшесі, Сұлтан Амин ауруханасы,, Джохор-Бару, Малайзия

\section{тҰЖЫРЫМДАМА}

Стационарда карбапенемге төзімді энтеробактериялардың инфекциясы жиілеп келеді. Инфекциядан кейін бұл аурудыңжоғарылауымен және өліммен байланысты. Карбапенемге төзімді энтеробактериялардың жалпы изоляттары - клебсиелла пневмониясы. Бұл зерттеуде Малайзиядағы Джохор-Бахру қаласындағы мемлекеттік ауруханада ашық жүрекке операция жасаған карбапенемге төзімді энтеробактерия тасымалдаушысы бар науқастың клиникалық жағдайы талқыланады.

Жалпы, зерттеудің мақсаты пациенттің энтеробактериялардың карбапенемге төзімді инфрекциясын тексеруге мүмкіндік беретін қауіпті фракторларды анықтау және энтеробактериялар жұқтырған карбапенемге төзімді пациент анықталғаннан кейін, әсіресе инфекцияның таралуын болдырмау және бақылау үшін қандай шараларды қолдануға болатындығын анықтау болды, әсіресе қарқынды терапия бөлімінде.

Негізгі сөздер: карбапенемге төзімді энтеробактерия, ашық жүрек хирургиясы, қарқынды терапия бөлімшесі, инфекциямен күрес

МЕРЫ ПО БОРЬБЕ С ИНФЕКЦИЕЙ У КАРБАПЕНЕМ-РЕЗИСТЕНТНОГО НОСИТЕЛЯ ЭНТЕРОБАКТЕРИИ ПОСЛЕ ОПЕРАЦИИ НА ОТКРЫТОМ СЕРДЦЕ В ОТДЕЛЕНИИ КАРДИОРЕАНИМАЦИИ: КЛИНИЧЕСКИЙ СЛУЧАЙ

Г. Сингх ${ }^{1}$, С.Дж. Вендаргон ${ }^{1}$, С.Р. Хамид ${ }^{1}$, М. Зайд ${ }^{2}$

${ }^{1}$ Отделение кардиоторакальной хирургии, Больница Султана Амина, Джохор-Бару, Малайзия

${ }^{2}$ Отделение инфекционных болезней, Больница Султана Амина, Джохор-Бару, Малайзия

\section{PEЗЮME}

Частота случаев карбапенем-резистентной инфекции энтеробактерии в условиях стационара растет. После заражения это связано с повышенной заболеваемостью, а также смертностью. Распространенными изолятами карбапенем-резистентной инфекции энтеробактерии является клебсиелла пневмонии. Данное исследование посвящено обсуждению клинического случая пациента, карбапенем-резистентного носителя энтеробактерии, перенесшего операцию на открытом сердце в государственной больнице в Джохор-Бару, Малайзия. В целом, целью исследования стало выявить факторы риска, которые позволят обследовать пациента на наличие карбапенем-резистентной инфекции энтеробактерии и после того, как выявлен карбапенем-резистентный пациент, зараженный энтеробактерией, определить какие меры могут быть приняты для предотвращения и контроля распространения инфекции, особенно в отделении интенсивной терапии.

Ключевые слова: карбапенем-резистентная энтеробактерия, операция на открытом сердце, отделение интенсивной терапии, борьба с инфекцией 


\section{Introduction}

Carbapenem-resistant Enterobacteriaceae (CRE) infection is frequently being encountered within healthcare setting. They are associated with high morbidity, attributable mortality and increased hospital costs. In Malaysia the New Delhi metallo- $\beta$ lactamase-1 (NMD-1) gene was first detected in carbapenemresistant Klebsiella pneumoniae (CRKP) in 2010. According to Malaysia National Surveillance Antimicrobial Resistance (NSAR) which involves 41 participating hospitals, prevalence of CRKP has increased in the recent years, from $0.3 \%$ in 2011 to $2.8 \%$ in 2015 . The Surveillance also reported a rapid increase in the number of cases from 28 cases in 2011 to more than 800 cases in $2016.95 \%$ of the patients have history of antibiotic exposure and $50.6 \%$ has history of antibiotic exposure of more than 7 days. Polymixin resistance CRE cases were also reported and it contributed to $21.7 \%$ Polymixin resistant enterobacteriaceae attributable death in year 2016 [1].

A study done by Antonia Salsano et al. showed that out of 553 patients undergoing open heart surgery, 32 (6\%) developed Carbapenem-resistant Klabsiella pneumomiae infection leading to an increased in-hospital mortality and 180-day mortality as compared to those who were not infected [2]. The common carriage of CRE is in the gastrointestinal tract and active screening can be done via swabs from rectal and peri-rectal areas or other areas or sites that is either infected or considered to be colonized. Therefore, it is important to implement preliminary supplemental measures for 'at risk' as well as confirmed cases of CRE infection to halt the entry and spread of CRE.

\section{Case presentation}

Patient T., 70 years old Chinese male, with underlying hypertension, was admitted to the medical ward, Hospital Sultanah Aminah, Johor Bahru for NSTEMI with cardiogenic shock. His prolonged hospitalization was due to Hospital Acquired Infection. He received broad spectrum antibiotics including carbapenems to which he subsequently responded. Rectal swab during his hospitalization during contact screening isolated Carbapeneam-resistant Enterobacteriaceae (CRE) Klebsiella Pneumoniae identified patient T. as a CRE carrier. Unfortunately, due to carrier status, further phenotypic testing of CRE from non CP-CRE or molecular testing for NDM was not done for his sample. Coronary angiogram showed three vessel coronary artery disease with left main stem involvement. Early Coronary Artery Bypass Graft Surgery (CABG) was indicated in his condition. He was screened negative for MRSA carrier. Subsequently he underwent a coronary artery bypass graft surgery on day 20 of hospitalization. Intraoperatively, intravenous Cephazolin $1 \mathrm{~g}$ was administered every 2 hours. Post operatively, patient $\mathrm{T}$. was nursed in the isolation room of the cardiac intensive care unit (CICU). In the CICU, strict contact precautions isolation measures were practiced to prevent spread of infection to other patients. All health care workers and visitors wore protective gowns and gloves when in contact with the patient. 5 moments of hand hygiene were strictly adhered. A dedicated nurse was assigned to the patient alone each shift during his hospitalization. Supplementary infection prevention measures including daily baths with no-rinse $2 \%$ chlorhexidineimpregnated wash cloths was done. Surfaces surrounding the patient were disinfected 2 times a day. His post operative progress was uneventful with no evidence of post operative sepsis and wound infection. He was discharged well on post operative day 6. There were no other CRE infections nor any patients within the ward detected to have any CRE pathogen.

\section{Discussion}

Antimicrobial resistance is an increasing concern within hospital settings. Patients who have been identified as carrier of multidrug resistance organism are at risk of developing MDR infections and at risk of transmitting infection to other patients. The decision between appropriate timing of surgery versus risk of probable post surgical complications have to be considered. Proper management of a CRE carrier patient post surgery is pivotal in preventing outbreaks within a healthcare setting.

Magiorakos et al identified certain epidemiological exposures that place patients "at-risk". They include overnight stay of a patient in a healthcare setting in the last 12 months a history of previous carriage of CRE within the last 12 months and has the patient been previously epidemiologically linked to a known CRE carrier [3]. Any of the above risk factors warrants a patient to be screened for CRE on admission. In our hospital, screening all patients with risk factors for CRE is not practically possible in our setting due to financial constraints. As most patients of CRE carriers are undiagnosed, contact/ linkage with these patients are frequently undetected. Another possible pitfall from screening patients for CRE is obtaining a false negative result due to intermittent rectal shedding of the CRE. False negative can occur due to the lack of protocols that are standardized for sampling and microbiological testing and prior usage of antimicrobials [3].

When CRE carrier is identified, prevention and control measures must be undertaken for all patients during their stay in the healthcare setting. The core measures that should be applied include antimicrobial stewardship, hand hygiene and microbiological capacity [3]. Due to the increased resistance faced with antimicrobials, appropriate antimicrobials prescribing is essential by doctors. Inappropriate use of antimicrobials may include treating colonizers, inadequate dose or frequency and prolonged duration than necessary. Healthcare settings on the other hand should be equipped with laboratories that have the competence and capacity to detect both clinical and screening samples. Results that are positive must be conveyed in a timely manner to those who are directly in contact with the patient so that early precautionary measures can be undertaken [3]. The importance of hand hygiene cannot be stressed enough in the prevention of CRE transmission. A study by Pittet D. et al demonstrated that hand hygiene remains the single most important and effective measure in the cross transmission of Multi Drug Resistant Organisms and Hospital Acquired Infections [4]. Morgan et al found that $8.2 \%$ of healthcare workers had at least 1 species of MDR bacteria on their hands before even entering the patient's room [5]. All the above measures are available and implemented in our facility. Other measures particularly for at risk patients should include patient isolation and decision on patient placement which is to limit CRE transmission. Ideally they must be placed in a single room with en suite bathroom. Additional Standard Precaution measures such as cleaning measures, waste management and designating nursing staff to care only for the MDRO/CRE patient during his/her shift. Contact precaution as well as proper communication between healthcare personnel during patient is equally important to prevent outbreak in other healthcare setting. Abboud C.S. et al, in his study concluded that the rates of CRE colonization, primary central line related infections and surgical site infections did decrease significantly and the measures are effective in controlling colonization and infection with CRE in the Cardiac ICU [6]. 


\section{Conclusion}

Infectious complications post cardiac surgery occur up to $5 \%$ to $21 \%$ of cases with an increase in post operative mortality by more than 5 times and prolonged recovery [6]. CRE infection will further complicate situations leading to increased mortality and morbidity. This is the first CRE carrier patient that we had conducted CABG. We would like to emphasize proper and effective infectious control measures in a patient undergoing open heart surgery in the perioperative state to prevent unwanted complications to the patient as well as to other patients. Antimicrobial stewardship, effective hand hygiene, microbiological capacities, patient isolation, nurse cohorting, contact precaution and effective exchange of information during patient transfer are pivotal steps to prevent spread of CRE infection particularly in the Cardiac Intensive Care Unit setting. Although simple, these measures are commonly underestimated among staff managing these patients. The above measures prove to be a factor to zero transmission of CRE in our facility. To conclude, we would urge healthcare personnel particularly in the intensive care setting to understand the implication of CRE and the threat it may pose to patients but with proper precautions execution, a good outcome is achievable.

Disclosures: There is no conflict of interest for all authors.

Patient informed consent: obtained.

\section{References}

1. Malaysian action plan on antimicrobial resistance (MyAP-AMR) 2017-2021, Ministry of Health Malaysia, 2018.

2. Salsano A, Giacobbe DR, Sportelli E, Olivieri GM, Brega C, Coppo E et al. Risk factors for infections due to carbapenem-resistant Klebsiella pneumoniae after open heart surgery. Interactive CardioVascular and Thoracic Surgery. 2016; 23 (5):762-768. https://doi. org/10.1093/icvts/ivw228

3. Magiorakos AP, Burns K, Baño JR, Borg M, Daikos G, Dumpis U, Lucet JC et al. Surgical site infection rates following cardiac surgery: the impact of a 6-year infection control program. Am J Infect Control. 2005; 33(8):450-454. https://doi.org/10.1016/j.ajic.2005.07.002

4. Pittet D, Hugonnet S, Harbarth S, Mourouga P, Sauvan V, Touveneau S et al. Effectiveness of a hospital-wide programme to improve compliance with hand hygiene. Infection Control Programme. Lancet. 2000; 356(9238):1307-1312. https://doi.org/10.1016/S01406736(00)02814-2

5. Morgan D, Rogawski E, Thom KA, Johnson JK, Perencevich EN, Shardell M et al. Transfer of multidrug-resistant bacteria to healthcare workers' gloves and gowns after patient contact increases with environmental contamination. Crit Care Med. 2012; 40(4):1045-1051. https://doi.org/10.1097/CCM.0b013e31823bc7c8

6. Abboud CS, de Souza EE, Zandonadi EC, Borges LS, Miglioli L, Monaco FC et al. Carbapenem-resistant Enterobacteriaceae on a cardiac surgery intensive care unit: successful measures for infection control. J Hosp Infect. 2016; 94(1):60-64. https://doi.org/10.1016/j. jhin.2016.06.010

How to cite this article: Gurpreet Singh, Simon Jerome Vendargon, Syed Rasul G Syed Hamid, Masliza Zaid. Measures for infection control in a Carbapenem-resistant Enterobacteriae carrier post open heart surgery in the cardiac intensive care unit: A case report. J Clin Med Kaz. 2020; 3(57):45-47 